\title{
Serotonin, beta-amyloid, and cognition in Parkinson disease
}

Running title: Serotonin medications in PD

Authors

Vikas Kotagal MD MS ${ }^{1,2}$, Cathie Spino Sc.D. ${ }^{3,4}$, Nicolaas I Bohnen MD PhD 1, 2, 3, 5 , Robert A. Koeppe ${ }^{5}$, and Roger L Albin MD ${ }^{1,2,3}$

1. Department of Neurology, University of Michigan, Ann Arbor, MI

2. Veterans Affairs Ann Arbor Health System (VAAAHS), Ann Arbor, Michigan

3. University of Michigan Morris K. Udall Center of Excellence for Parkinson's Disease Research, Ann Arbor, MI

4. Department of Biostatistics, School of Public Health, University of Michigan, Ann Arbor, MI

5. Department of Radiology, Division of Nuclear Medicine, University of Michigan, Ann Arbor, MI

Corresponding Author:

Vikas Kotagal Building 14, North Campus Research Complex University of Michigan 2800 Plymouth Road

Ann Arbor MI, 48109 vikaskot@med.umich.edu

Phone: 734-936-9010

Fax: 734-615-4991

Keywords: Parkinson disease, SSRIs, amyloid, cognition, PPMI

Title character count: 55

Running title character count: 27

Abstract word count: 250

Introduction word count: 437

Discussion word count: 1631

Manuscript word count: 3917

References: 50

Figures: 2

Tables: 4

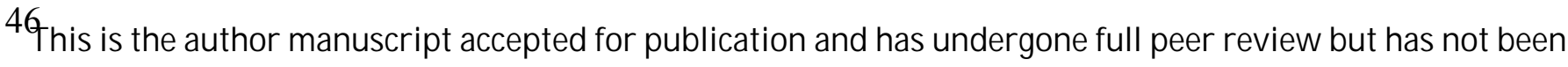
through the copyediting, typesetting, pagination and proofreading process, which may lead to differences between this version and the Version of record. Please cite this article as doi:10.1002/ ana.25236. 
Kotagal, et al. 2

\section{Abstract}

2

3 Objective: Serotoninergic neurotransmission may modulate beta-amyloid peptide (A $\beta)$

4 metabolism through up-regulation of alpha-secretase. Early Parkinson disease (PD)

5 shows variable serotoninergic denervation, which may impact $A \beta$ deposition.

7 Methods: We conducted three analyses to explore associations between serotoninergic

8 neurotransmission and cerebral $A \beta$ burden in PD. The first was a cross-sectional

9 imaging study of PD subjects $(n=23)$ using the serotoninergic transporter positron

10 emission tomography (PET) ligand $\left[{ }^{11} \mathrm{C}\right] \mathrm{DASB}$ and amyloid PET Pittsburgh compound $\mathrm{B}$

$11\left(\left[{ }^{11} \mathrm{C}\right] \mathrm{PiB}\right)$. The second was a baseline study of Parkinson's Progression Markers

12 Initiative (PPMI) subjects exploring the influence of serotoninergic medications on

13 cerebrospinal fluid (CSF) A $\beta-42$ levels ( $n=389$ ), controlling for age, sex, Geriatric

14 Depression scale (GDS), disease duration, and education. Third, we fit an interval-

15 censored proportional hazard model with longitudinal PPMI data $(n=367)$ to test whether

16 serotoninergic medication use associates with reduced risk of PD-cognitive-decline,

17 defined as time to reach a Montreal Cognitive Assessment score $\leq 20$, adjusting for

18 baseline caudate dopamine transporter (DaT) $\left[{ }^{123} \mathrm{I}\right]$ loflupane single photon emission

19 computed tomography and cerebrospinal fluid $A \beta-42$ levels.

21 Results: Serotoninergic DASB distribution volume ratio (DVR) inversely associated with

$22 \mathrm{PiB}$ DVR in the cerebral cortex (Pearson's-r=-0.478, $\mathrm{p}=0.021)$ but not the striatum $(r=-$

$230.264, p=0.224$ ). In the baseline PPMI analysis, serotoninergic medication use for $\geq 6$

24 months associated with a lower level of CSF $A \beta-42(t=-2.20, p=0.029)$. In the longitudinal 
1 PPMI model, baseline serotoninergic medication use associated with a reduced risk of

2 cognitive decline $(t=-2.03, p=0.043)$ after controlling for covariates.

3

4 Interpretation: Cortical $\mathrm{A} \beta$ burden in $\mathrm{PD}$ associates inversely with serotoninergic

5 innervation. Serotoninergic medications may alter $A \beta$ metabolism and reduce the risk of

6 PD cognitive decline.

7

8

9

10

11

12

13

14

15

16

17

18

18

20

21

22

23
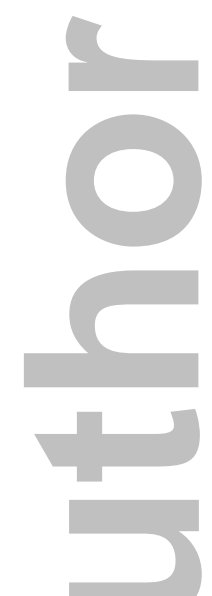
Kotagal, et al. 4

\section{Introduction}

Progressive cerebral beta-amyloid peptide $(A \beta)$ plaque burden is linked to

4 clinically meaningful outcomes--including cognitive decline ${ }^{1,2}$ and gait impairments ${ }^{3,4}$--

5 in Parkinson disease (PD) and synucleionpathy-associated dementias. A $\beta$ plaque deposition, assessed by amyloid positron emission tomography (PET), is associated

7 with prevalent cognitive impairment in parkinsonian conditions. ${ }^{5}$ Reduced cerebrospinal

8 fluid (CSF) A $\beta-42$ oligomers and factors influencing their metabolism are also

9 consistently reported as risk factors for subsequent cognitive decline in PD without

10 dementia. ${ }^{6-8}$ Developing strategies to alter the natural history of $A \beta$ burden in PD may

11 represent an untapped disease-modifying approach and is an emerging research

12 priority.

13 Variable loss of serotoninergic nerve terminals in the forebrain, striatum, and

14 brainstem is described in Parkinson disease. ${ }^{9,10}$ Significant loss of serotoninergic

15 terminals is an early feature in a substantial fraction of PD subjects. ${ }^{7,8}$ Preclinical

16 experiments in Alzheimer disease (AD) mouse models by Cirrito et al. showed that

17 chronic exposure to either serotonin itself or the selective-serotonin reuptake inhibitor

18 (SSRI) citalopram reduced extracellular cerebral A $\beta$ peptide concentrations and plaque

19 burden in short- and long- term in vivo studies. ${ }^{11,12}$ Serotonin and SSRIs are suggested

20 to stimulate a serotonin G-protein-coupled receptor-linked intracellular cascade that

21 favors the cleavage of Amyloid Precursor Protein (APP) by alpha-secretase, leading to

22 reductions in toxic $A \beta$ peptide amyloid generation and reduced plaque formation. ${ }^{11}$

23 Serotonin medications may also promote efflux of toxic $A \beta$ peptide species from the 
1 brain into the blood. ${ }^{13}$ Other preclinical research supports the concept that

2 serotoninergic neurotransmission can favorably modulate APP processing. ${ }^{14-17}$ If the

3 same protective association between serotonin receptor activation and reduced amyloid

4 burden exists in humans, a disease state such as PD with reductions in serotoninergic

5 tone offers a potential model for testing this hypothesis. In a small cohort, we previously

6 reported that regional density of cortical and striatal serotoninergic terminals in PD,

7 measured by in vivo positron emission tomography (PET), showed inverse correlations

8 with $A \beta$ plaque burden. ${ }^{18}$

$9 \quad$ We present three analyses exploring associations between serotoninergic

10 neurotransmission and $A \beta$ burden in $P D$, using different experimental designs to

11 address 3 related hypotheses. First, using an identical multimodal imaging approach to

12 our earlier study in a new cohort, we sought to replicate our findings that decreased

13 cortical serotoninergic innervation is inversely associated with the severity of cortical $A \beta$

14 plaque burden in PD. Second, using baseline data from the multicenter Parkinson

15 Progression Markers Initiative (PPMI), we explored associations between serotonin

16 medication use and CSF A $\beta-42$ levels. Third, we used a longitudinal analysis of PPMI

17 data to test whether baseline serotoninergic medication use associates with a protective

18 effect on cognitive decline in PD, independent of existing heterogeneity in caudate

19 dopamine transporter binding or baseline cerebral amyloid burden.

\section{Methods}

23 Study 1: Cross-sectional prospective PET imaging study 
Kotagal, et al. 6

In a previous PD cohort $(n=13)$, we reported inverse associations between cortical and striatal serotoninergic terminal and amyloid PET findings. ${ }^{18}$ To determine whether these findings were due to cohort specific effects, we conducted a separate cross-sectional multimodal PET imaging study of 23 PD subjects. Inclusion criteria included age $\geq 45$, a diagnosis of PD as determined by the UK Parkinson's Disease Society Brain Bank Clinical diagnostic criteria, ${ }^{19}$ no evidence of atypical parkinsonism or neuroleptic-associated PD, no contraindications to undergo magnetic resonance imaging (MRI) such as indwelling metal hardware in the body, and no exposure to serotoninergic medications, anticholinergic medications, or cholinesterase inhibitors in the last 2 months. This study was reviewed by the University of Michigan IRBMED and all subjects signed informed consent prior to study enrollment.

Regional serotonin terminal density was assessed with the serotonin transporter PET ligand [ $\left.{ }^{11} \mathrm{C}\right] 3$-amino-4-(2-dimethylaminomethyl-phenylsulfaryl)-benzonitrile (DASB) and cerebral amyloid plaque deposition was measured with $\left[{ }^{11} \mathrm{C}\right]$ Pittsburgh compound $\mathrm{B}$ (PiB) PET as described previously. ${ }^{18}$ For 22 of the 23 subjects all MRI, DASB, and PiB PET scans took place within 1 week of each other. In one subject, the DASB and PiB scans were separated by 41 days. All PET studies were performed with bolus and infusion dynamic imaging protocols. Cortical and subcortical segmentation was performed with FreeSurfer version 5 in the fully automated mode. Total cortical and striatal regions were used for correlation analysis. All image frames were spatially coregistered within participants with a rigid-body transformation. Motion-corrected PET frames were spatially coregistered to the T1-weighted MRI using standard coregistration 
1 procedures in NeuroStat (https://neurostat.neuro.utah.edu/). Time activity curves for

2 each VOI were generated from the spatially aligned PET frames. DASB and PiB

3 distribution volume ratios (DVRs) were estimated by the Logan plot graphical analysis

4 method $^{20}$ with the time-activity curves as the input function and with the inferior posterior

5 cerebellum as reference tissue for both PiB and DASB. Pearson correlation coefficients

6 were used to assess the relationship of PiB and DASB DVRs in the total cortical and

7 striatal regions of interest. Using subject age, disease duration, years of education, and

8 cortical DASB DVR as covariates, we also conducted a multivariable linear regression

9 model with cortical PiB DVR as the outcome variable and a covariate significance level

10 for retention in the final model of 0.1 using a backwards-selection process. Interaction

11 terms were tested in the covariates retained in the final model and were included at a p-

12 value threshold of 0.1

14 Study 2a: Cross-sectional PPMI Baseline Analysis

The Parkinson's Progression Markers Initiative (PPMI) is a multicenter

17 longitudinal observational study of PD (http://www.ppmi-info.org/). Curated PPMI

18 datasets containing $A \beta-42$ measurements, primary diagnoses, and dopamine

19 transporter (DaT) $\left[{ }^{123}\right.$ ] loflupane single photon emission computed tomography (SPECT)

20 results were downloaded on 8/22/17. Datasets containing demographics and clinical

21 non-motor testing were downloaded between $10 / 10 / 2016$ and $1 / 13 / 2017$. PPMI subjects

22 underwent screening evaluations (month 0 ), followed by baseline evaluations (typically

23 at month 1), visit 1 evaluations (month 4), and subsequent evaluations on a scheduled 
1 basis-initially at 3 month intervals and then at 6 month intervals after visit 4 (month

2 13)--through a possible visit 12 (month 61). All subjects signed informed consent upon

3 enrollment into the PPMI. This project using publically available coded PPMI data was

4 granted not-regulated status by the University of Michigan IRBMED. Analyses were

5 conducted in STATA 15 (College Station, TX) and SAS 9.4 (Cary, NC).

$6 \quad$ Eligible subjects for our baseline analyses were those who were coded as having

7 a primary study diagnosis of "idiopathic PD" at the time of screening visit, a screening

8 visit DaT scan evaluation, who had CSF A $\beta-42$ tested at the baseline visit and

9 documentation of serotonin medication use at the time, and who did not accrue an

10 alternative primary study diagnosis at a subsequent study visit. Figure 1 provides an

11 overview of our PPMI study cohorts. We categorized serotoninergic medications to

12 include selective serotonin reuptake inhibitors (SSRIs) ${ }^{21}$, serotonin-norepinephrine

13 reuptake inhibitors $(\mathrm{SNRIs})^{22}$, tricyclic antidepressants $(\mathrm{TCAs})^{17}$, bupropion ${ }^{23}$, lithium ${ }^{24}$,

14 and St. John's Wort ${ }^{25}$ given that each of these compounds has been shown to influence

15 serotoninergic neurotransmission. In this cross-sectional baseline study aimed at

16 understanding the influence of serotonin medications on CSF A $\beta-42$, we categorized

17 subjects as those taking serotonin medications for $\geq 6$ months $(n=45)$ vs. others $(n=344)$.

18 Serotonin-medication-use was treated as a categorical variable (yes/no) and was not

19 adjusted for dosing or weight. Age was defined as the difference between year of birth

20 and year of study enrollment and disease duration was defined at the number of years

21 between when symptoms were first noticed by the subject and year of study enrollment.

22 According to the study protocol, CSF A $\beta-42$ levels $^{26}$ were measured at the baseline

23 visit. 
Baseline CSF A $\beta-42$ was treated as the outcome variable of interest in a multivariable linear regression using baseline cross-sectional PPMI data. Covariates

3 included serotonin medication use, age, sex, disease duration, self-reported years of

4 education, and baseline Geriatric Depression Scale (GDS) score on the 15-item GDS.

5 We aimed to control for the degree of depressive symptoms using the GDS since the

6 late-life depression is known to associate both with dementia risk and with CSF A $\beta-42$

7 burden. ${ }^{27,}{ }^{28}$ We controlled for years of education to account for the possibility that

8 subjects receiving prescription serotonin medications might have unmeasured

9 differences in socio-economic status relative to those not on serotonin medications.

We conducted a survival analysis in the PPMI cohort to explore the effects of

15 serotoninergic medications on cognitive decline in PD. PD subjects who had 2 or more

16 Montreal Cognitive Assessment (MoCA) scores recorded over the duration of the study,

17 who underwent DaT SPECT at screening, and who had a screening MoCA score of $>20$

18 at study entry were eligible for inclusion (Figure 1 ).

19 We chose progression to MoCA scores of 20 or less as our endpoint given that

20 this transition value (21->20) has been previously validated against full

21 neuropsychological testing in PD as an optimal diagnostic cutoff point (as opposed to a

22 "screening" cutoff value) for meeting neuropsychological criteria of impairment in at

23 least 2 cognitive domains suggestive of dementia. ${ }^{29}$ We aimed to define our MoCA 
1 endpoint as manifestation of a clear stage-progression milestone, and tried to

2 differentiate this endpoint from a transient drop in scoring that might improve at the next

3 visit. Subsequently, we defined our endpoint as having been met if a subject had 2 or

4 more consecutive visits with MoCA scores $\leq 20$ or if their final recorded MoCA score was

$5 \leq 20$. We qualified time-to-event as the month correlating with the planned visit

6 according to the PPMI schedule of activities: screening visit (month 0), visit 4 (month

7 13), visit 6 (month 25), visit 8 (month 37), visit 10 (month 49), through visit 12 (month

8 61). To account for the possibility of missed study visits and the likelihood of that not all

9 study visits took place at the identical time interval, we conducted a survival analysis

10 using interval censoring with a Weibull proportional hazard distribution. Subjects whose

11 MoCA scores progressed from $>20$ at screening visit (month 0 ) to $\leq 20$ by visit 4 (month

12 13) were identified as having progressed to the MoCA endpoint in an interval between 1

13 and 13 months in order to categorized as interval-censored rather than left censored. All

14 other subjects were considered right censored at the time of their final recorded MoCA

15 score. Of note, an inclusion criteria for enrollment in the PPMI was that subjects were

16 "not expected to require PD medication within at least 6 months from baseline"

17 (http://www.ppmi-info.org/study-design/). ${ }^{30}$ Subsequently, none of our longitudinal PPMI

18 subjects were on dopaminergic PD medications at study enrollment.

19 We first tested the unadjusted bivariate associations between several different

20 potential explanatory variables including the use of serotoninergic medications at the

21 time of baseline evaluation (Supplementary Table 1) in separate Cox-proportional

22 hazard analyses. Next, we tested associations in a multivariable model after adjusting

23 for several baseline confounders. The nigrostriatal dopaminergic system is known to 
1 play a role in PD cognitive impairment, specifically dopamine terminal loss in the

2 caudate nucleus. ${ }^{31,32}$ We estimated this using mean bilateral caudate nucleus DaT

3 SPECT measurements from the PPMI. ${ }^{33}$ We sought to control for heterogeneity in

4 baseline amyloid status by using baseline CSF A $\beta-42$ levels as a covariate as well.

5 Covariates were tested to explore the assumption of proportional hazards. To test

6 whether a serotonin-medication effect on MoCA decline might vary across drug classes

7 of differing specificity for serotonin-receptor modulation, we conducted two separate

8 sensitivity analyses where the serotonin medication use categorical variable was

9 restricted to either only those subjects taking SSRIs or those subjects taking either

10 SSRIs or TCAs.

12 Results

Demographic characteristics for the Study 1 cohort are presented in Table 1. In

15 the multi-modal PET imaging study, cortical serotoninergic terminal density correlated

16 inversely with cortical amyloid burden (Pearson's $r=-0.478, p=0.021$; Figure 2). Striatal

17 serotoninergic terminal density did not significantly correlate with striatal amyloid

18 deposition (Pearson's $r=-0.264, p=0.224$ ). In our multivariable linear regression model of

19 cortical PiB DVR, disease duration and cortical DASB DVR were retained at a covariate

20 threshold of $p<0.1$. The final model $(F=5.11, p=0.0161)$ showed an $R^{2}$ of 0.338 with a

21 significant association seen for cortical DASB DVR $(t=8.13, p=0.0099)$ and a non-

22 significant associative trend for duration of disease $(t=3.32, p-0.0836)$. There were no

23 significant interactions between cortical DASB DVR and disease duration. 
Kotagal, et al. 12

In Study 2a, subjects on serotonin medications for at least 6 months at baseline

$2(n=45)$ did not differ significantly in CSF $A \beta-42$ levels from subjects not receiving

3 serotonin medications in unadjusted analyses (mean +/- SE: $348.5 \mathrm{pg} / \mathrm{ml}+/-15.0$ vs.

$4374.5 \mathrm{pg} / \mathrm{ml}+/-5.5 ; \mathrm{t}=1.62, \mathrm{p}=0.11)$. After adjusting for confounders, the multivariable

5 linear regression analyses $(n=389$; Table 2$)$ showed that male sex and use of serotonin medications for at least 6 months both associated with lower levels of CSF A $\beta-42$ at

7 baseline. Age, disease duration, years of education, and GDS score, did not show

8 significant associations.

367 subjects met inclusion criteria for the survival analysis (Study $2 b$ ) predicting

10 time to a decline in MoCA score of $\leq 20$. Of these 367 subjects, $70(19.1 \%)$ were using

11 serotoninergic medications at the time of their baseline visit. 28 of the total 367 subjects

12 progressed to develop a MoCA score of 20 as assessed at a subsequent study visit. In

13 a bivariate Cox-proportional hazard analysis, taking a serotoninergic medication at

14 baseline did not show a significant association with decline to a MoCA of $\leq 20$

15 (Supplementary Table 1). Table 3 shows the results of a multivariable interval-censored

16 model controlling for the confounder effects of screening caudate nucleus DaT SPECT

17 binding ratio and baseline CSF A $\beta-42$ levels. In this model, serotoninergic medication

18 use at baseline showed a protective association with reduced likelihood of MoCA

19 decline. Sensitivity analyses of this interval-censored multivariable model using

20 different definitions of serotonin-medications revealed comparable but non-significant

21 trends between both SSRI $(n=49$ out of 367 ; Hazard ratio $=0.185$, SE $=0.189[95 \% \mathrm{CI}$ :

$220.025,1.372], Z=-1.65, p=0.099)$ use and/or the combination of either SSRI or TCA 
$1 \quad(n=54$ out of $367 ;$ Hazard ratio $=0.170, S E=0.173[95 \% \mathrm{Cl}: 0.023,1.257], Z=-1.74, p$

$2=0.083)$ use with the risk for MoCA decline.

3

4

5 Discussion

6 22 control subjects and other showing marked loss of serotonin terminal markers. ${ }^{34}$ PET 23 studies suggest that regional serotonin terminal loss is an early event in PD. ${ }^{10,36}$ This

We present findings from converging lines of evidence supporting the hypothesized relationship between serotoninergic neurotransmission and cerebral amyloid burden in PD. Study 1 confirms our previous imaging findings of a relationship between reduced serotonin terminals in the cortex and the increased severity of cerebral amyloid plaque burden in PD. Study 2a shows an association between serotoninergic medication exposure for $\geq 6$ months and lower CSF A $\beta-42$ levels. Study $2 b$ suggests that serotoninergic medication exposure at baseline is associated with a reduced risk for progression to a MoCA score of $\leq 20$. Collectively, these findings support the concept that serotoninergic medications favorably associate and/or alter cerebral $A \beta$ peptide activity in $P D$.

Post-mortem studies of PD show reductions in serotonin terminal markers in numerous cortical and subcortical regions. ${ }^{34,35}$ Consistent with in vivo PET imaging results, analysis of post-mortem specimens by Buddhala et al. showed that serotoninergic terminal loss in PD exhibits considerable variation with many PD subjects exhibiting regional serotonin terminal markers levels comparable to those found in 
1 early and heterogeneous loss of serotoninergic terminals may suggest a possible causal role for serotoninergic modulation of $A \beta$ peptide generation in $P D$, the latter of

3 which is a later-stage disease feature that also shows substantial heterogeneity in

4 cortical plaque burden. ${ }^{5}$ In contrast to our initial findings, we did not find a significant

5 correlation between striatal DASB and PiB DVRs in the current cohort. This may reflect

6 stage-specific associations not seen in our cohort given that striatal amyloid burden has

7 been described more commonly in PD with advanced cognitive impairment as opposed

8 to early PD. ${ }^{37,38}$ Within the range of values seen in our Study 1 cohort however, disease

9 duration did not appear to influence the association between cortical and DSAB and PiB

10 DVRs. Understanding temporal associations between early regional serotonin terminal

11 loss and progressive amyloid plaque deposition leading to local neuronal dysfunction

12 may be a fruitful goal for future PD natural history studies. Our Study $2 a$ analysis results indicating lower CSF A $\beta-42$ levels in PD subjects

14 taking serotoninergic medications are consistent with recent preclinical and clinical data

15 suggesting that increasing serotoninergic neurotransmission reduces $A \beta$ peptide

16 generation. Cirrito et al demonstrated that chronic oral administration of citalopram

17 relative to placebo in an $A D$ model mice diminished extracellular $A \beta$ peptide levels and

18 led to a $62 \%$ reduction in relative cortical amyloid plaque burden after 4 months. ${ }^{11}$ In a

19 retrospective analysis of 177 healthy controls, the duration of serotonin medication

20 exposure correlated with reduced cortical amyloid PET binding. ${ }^{11} \mathrm{~A}$ separate

21 prospective randomized trial of young healthy adults showed that those receiving an

22 acute $60 \mathrm{mg}$ dose of citalopram rather than placebo experienced a $38 \%$ reduction over

23 about 2 days in CSF A $\beta$ peptide concentrations and the kinetics of this reduction was 
1 consistent with reduced $A \beta$ peptide generation. ${ }^{12}$ Although higher $A \beta-42$ CSF levels are

2 typically associated with better cognitive outcomes in PD, interpretation of $A \beta-42$ CSF

3 level data is not straightforward. generation, clearance, and possibly sequestration in amyloid plaques. Some evidence

6 suggests that reduced Abeta-42 levels would be consistent with reduced risk of

7 dementia. In vitro data indicates that the protective APP A673T mutation is associated

8 with reduced A $\beta-42$ generation. ${ }^{39}$ Recent evidence from APP A673T mutation carriers

9 show reduced serum levels of $A \beta-42$, which is expected to correlate with CSF $A \beta-42$

10 levels. $^{40}$ Similarly, increased $A \beta-42$ generation is predicted to increase dementia risk.

11 Statistical modelling of CSF A $\beta-42$ data from autosomal dominant Alzheimer disease

12 (ADAD) mutant allele carriers followed in the Dominantly Inherited Alzheimer Network

13 (DIAN) study suggests early elevation of CSF $A \beta-42$ levels followed by decline around

14 the estimated onset of manifest disease.$^{41}$ In this model, declining CSF A $\beta-42$ levels in

15 ADAD subjects is secondary to neurodegeneration causing diminished $A \beta-42$ peptide

16 generation and/or $A \beta-42$ peptide sequestration in amyloid plaques. The implication is

17 that the association between lower CSF A $\beta-42$ levels and dementia risk is a

18 consequence of more advanced pathology.

19 Our finding (Study $2 b$ ) that baseline serotoninergic medication exposure reduced

20 risk of progression to MoCA $<20$ is also consistent with a beneficial modulatory effect of

21 serotoninergic agents on $A \beta-42$ peptide generation. Similar results were reported

22 recently in a retrospective analysis of conversion from Mild Cognitive Impairment to

23 dementia in the Alzheimer Disease Neuroimaging (ADNI) cohort. ${ }^{42}$ Antidepressant 
1 medications were also suggested to reduce dementia incidence in analyses from

2 Kessing et al. in datasets drawn from large Danish registries of prescription drugs. ${ }^{43,44}$

3 Our sensitivity analyses did not show significant associations between SSRIs and

4 SSRIs/TCAs with time to MoCA decline. Given the relatively similar hazard ratios but

5 increased hazard ratio standard errors for the serotonin-medication-use variable in

6 these subgroup analyses, these findings may be a manifestation of an expected

7 reduction in statistical power with fewer subjects subsequently identified as having the

8 exposure of interest. ${ }^{45}$ Alternatively, they may reflect either the possibility that non-

9 serotonin neuronal systems are preferentially involved in altering the risk or PD

10 cognitive decline or the possibility that only a low-degree of serotonin-receptor

11 modulation may be needed to yield a protective cognitive effect.

12 Serotoninergic medications are used early and often in PD to treat symptoms of

13 depression, anxiety, sleep disorders, or other non-motor features. In the PPMI cohort, 14 about $20 \%$ of subjects were on serotoninergic medications at baseline. A community-

15 based PD registry study in Sweden estimated the rate to be $22 \%$ in home-dwelling

16 individuals and $50 \%$ in those residing in an institution. ${ }^{46}$ To date, PD trials that have

17 focused on the efficacy of SSRIs, SNRIs, or TCAs, typically employed relatively short

18 study assessment periods (weeks to months) focused on symptomatic modification of

19 self-reported affective symptoms and have not measured cerebral amyloid burden. ${ }^{47,48}$

20 One post-hoc analysis of a 4-month randomized PD-antidepressant trial showed no

21 clear benefit to paroxetine or nortriptyline on cognitive performance relative to placebo

22 but was limited to a small sample size and short follow-up duration. ${ }^{49}$ The possible

23 beneficial effect of certain TCAs on amyloid-linked cognitive decline may also be 
1 confounded by their anticholinergic properties. A systematic review by Moraros et al.

2 investigated the association between antidepressant drugs and dementia risk and found

3 a higher unadjusted dementia risk in subjects initiated on antidepressants before age

$4 \quad 65 . .^{50}$ These findings are likely to be influenced by the severity and variable causes of

5 comorbid depression. They do, however, raise the possibility that there may exist a

6 critical time window for serotonin-neurodegeneration-induced acceleration of cerebral

7 amyloid burden. This may be relevant for the design of future interventional studies. Our

8 Study $2 b$ clinical findings would benefit from validation not only in other PD cohorts but

9 also in prospective longitudinal studies of aging that could control for drug class and

10 dosing.

11 Limitations of our study include the possibility of differential censoring. Only a

12 small fraction of eligible subjects progressed to a MoCA score of 20 or less, raising the

13 possibility that some subjects with declining cognition might have been lost to follow-up

14 and would thereby not be captured in this dataset. It is possible that such censoring

15 occurred and may influence these data. Subjects enrolled in the PPMI may represent a

16 skewed population given that their parkinsonian symptoms were not severe enough to

17 require the use of dopaminergic medications at the time of enrollment. This cohort factor

18 may limit the generalizability of our findings. Because of power concerns, we were not

19 able to control for a greater number of covariates given the limited number of subjects

20 who did progress to the MoCA endpoint. Some PPMI subjects showed variability in

21 MoCA scoring from one visit to the next. We chose our endpoint specifically for purpose

22 of accurately identifying newly developed probable dementia rather than as a screening

23 cut-off for subjects at risk for dementia. This effort to more precisely define a cognitive 
1 state transition endpoint limited the number of PPMI subjects who met our primary

2 endpoint. This trade-off, however, comes with improved precision as it relates to our

3 assessment of baseline risk factors associated with longitudinal cognitive decline. Our

4 previously published cross-sectional DASB-PiB PD PET imaging cohort ${ }^{18}$ had an even

5 higher mean age (68.38) and lower mean MoCA (24.3) than the 23 subject imaging

6 cohort in Study 1 . In the present analyses, subjects enrolled in Study 1 were older, had

7 longer disease duration, and lower MoCA scores than subjects in the PPMI. This may

8 limit how translatable findings from Study 1 are to the cohort in Study 2 and vice versa.

9 On the other hand, these findings may also collectively shed light into different aspects

10 of the natural history of serotoninergic neurodegeneration across different disease

11 stages in PD.

12 We acknowledge that our findings do not directly test the protective causal

13 mechanism that we hypothesize exists between serotoninergic medications, alpha-

14 secretase activity, and the degree of cerebral amyloid burden in PD. It is possible that

15 subjects in this cohort receiving serotoninergic medications from their personal

16 clinicians may have other unmeasured factors that influence amyloid burden and/or

17 cognition, including severity and subtypes of affective symptoms or factors that

18 associate with greater access to care and prescription medications. Given the wide

19 variety, dosing, and duration of use of serotoninergic medications by subjects, we were

20 not able to explore a dose-response relationship.

21 Developing treatments for different causes of cerebral amyloid burden is a goal

22 relevant not only to PD but to a majority of patients affected by neurodegenerative

23 diseases. Our PD findings are strengthened by the multi-center nature of the PPMI but 
1 would benefit from replication in other representative PD datasets. Serotoninergic

2 medications are well tolerated in PD patients and trials of SSRIs targeted against

3 cerebral amyloid burden merit consideration for future PD clinical trials. Such trials

4 might be usefully enhanced by use of serotonin terminal imaging to select or stratify the

5 subject population.

6

9 Acknowledgements

10 We thank all study participants who generously donated their time and effort.

\section{Author contributions}

13 VK, RLA, and NIB designed the study, VK, CS, RLA, and RAK acquired and analyzed

14 the data. VK, NIB, and RLA drafted the manuscript which was reviewed and revised by

15 all coauthors.

16

\section{Potential Conflicts of Interest}

19 None to report

20

21

22

23 
Kotagal, et al. 20

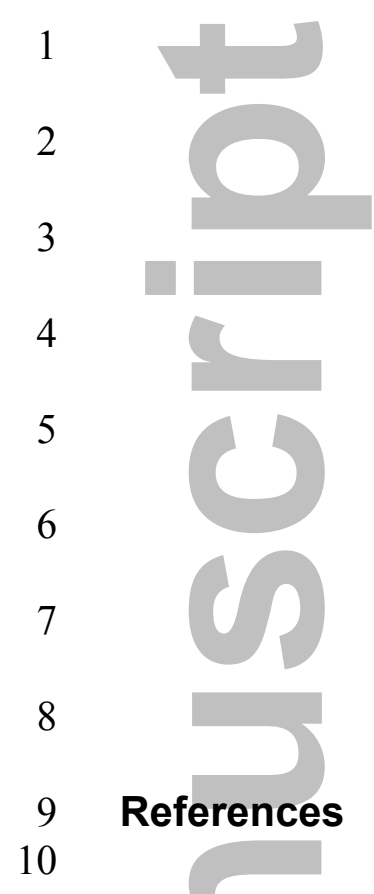

11 1. Aarsland D, Creese B, Politis M, et al. Cognitive decline in Parkinson disease.

12 Nature reviews Neurology. 2017 Apr;13(4):217-31.

13 2. Petrou M, Bohnen NI, Muller ML, Koeppe RA, Albin RL, Frey KA. Abeta-amyloid

14 deposition in patients with Parkinson disease at risk for development of dementia.

15 Neurology. 2012 Sep 11;79(11):1161-7.

16 3. Rochester L, Galna B, Lord S, et al. Decrease in Abeta42 predicts dopa-resistant

17 gait progression in early Parkinson disease. Neurology. 2017 Apr 18;88(16):1501-11.

18 4. Muller ML, Frey KA, Petrou M, et al. beta-Amyloid and postural instability and

19 gait difficulty in Parkinson's disease at risk for dementia. Movement disorders : official

20 journal of the Movement Disorder Society. 2013 Mar;28(3):296-301.

21 5. Petrou M, Dwamena BA, Foerster BR, et al. Amyloid deposition in Parkinson's

22 disease and cognitive impairment: a systematic review. Movement disorders : official

23 journal of the Movement Disorder Society. 2015 Jun;30(7):928-35. 
1 6. Terrelonge M, Jr., Marder KS, Weintraub D, Alcalay RN. CSF beta-Amyloid 1-42

2 Predicts Progression to Cognitive Impairment in Newly Diagnosed Parkinson Disease.

3 Journal of molecular neuroscience : MN. 2016 Jan;58(1):88-92.

47 Brockmann K, Lerche S, Dilger SS, et al. SNPs in Abeta clearance proteins:

5 Lower CSF Abeta1-42 levels and earlier onset of dementia in PD. Neurology. 2017 Nov 608.

7 8. Johar I, Mollenhauer B, Aarsland D. Cerebrospinal Fluid Biomarkers of Cognitive

8 Decline in Parkinson's Disease. International review of neurobiology. 2017;132:275-94.

9 9. Albin RL, Koeppe RA, Bohnen NI, Wernette K, Kilbourn MA, Frey KA. Spared

10 caudal brainstem SERT binding in early Parkinson's disease. Journal of cerebral blood

11 flow and metabolism : official journal of the International Society of Cerebral Blood Flow

12 and Metabolism. 2008 Mar;28(3):441-4.

13 10. Pagano G, Niccolini F, Fusar-Poli P, Politis M. Serotonin transporter in

14 Parkinson's disease: A meta-analysis of positron emission tomography studies. Annals

15 of neurology. 2017 Feb;81(2):171-80.

16 11. Cirrito JR, Disabato BM, Restivo JL, et al. Serotonin signaling is associated with

17 lower amyloid-beta levels and plaques in transgenic mice and humans. Proceedings of

18 the National Academy of Sciences of the United States of America. 2011 Sep

19 06;108(36):14968-73.

20 12. Sheline YI, West T, Yarasheski K, et al. An antidepressant decreases CSF Abeta

21 production in healthy individuals and in transgenic AD mice. Science translational

22 medicine. 2014 May 14;6(236):236re4. 
1 13. Brenn A, Grube M, Jedlitschky G, et al. St. John's Wort reduces beta-amyloid

2 accumulation in a double transgenic Alzheimer's disease mouse model-role of $\mathrm{P}$ -

3 glycoprotein. Brain Pathol. 2014 Jan;24(1):18-24.

4 14. Nitsch RM, Deng M, Growdon JH, Wurtman RJ. Serotonin 5-HT2a and 5-HT2c

5 receptors stimulate amyloid precursor protein ectodomain secretion. The Journal of

6 biological chemistry. 1996 Feb 23;271(8):4188-94.

715. Postina R. Activation of alpha-secretase cleavage. Journal of neurochemistry.

$8 \quad 2012$ Jan;120 Suppl 1:46-54.

9 16. Lezoualc'h F. 5-HT4 receptor and Alzheimer's disease: the amyloid connection.

10 Experimental neurology. 2007 Jun;205(2):325-9.

11 17. Li X, Wang Q, Hu T, et al. A tricyclic antidepressant, amoxapine, reduces

12 amyloid-beta generation through multiple serotonin receptor 6-mediated targets.

13 Scientific reports. 2017 Jul 10;7(1):4983.

14 18. Kotagal V, Bohnen NI, Muller ML, Koeppe RA, Frey KA, Albin RL. Cerebral

15 amyloid deposition and serotoninergic innervation in Parkinson disease. Archives of

16 neurology. 2012 Dec;69(12):1628-31.

17 19. Hughes AJ, Daniel SE, Kilford L, Lees AJ. Accuracy of clinical diagnosis of

18 idiopathic Parkinson's disease: a clinico-pathological study of 100 cases. Journal of

19 neurology, neurosurgery, and psychiatry. 1992 Mar;55(3):181-4.

$2020 . \quad$ Logan J, Fowler JS, Volkow ND, Wang GJ, Ding YS, Alexoff DL. Distribution

21 volume ratios without blood sampling from graphical analysis of PET data. Journal of

22 cerebral blood flow and metabolism : official journal of the International Society of

23 Cerebral Blood Flow and Metabolism. 1996 Sep;16(5):834-40. 
1 21. Dempsey CM, Mackenzie SM, Gargus A, Blanco G, Sze JY. Serotonin (5HT),

2 fluoxetine, imipramine and dopamine target distinct $5 \mathrm{HT}$ receptor signaling to modulate

3 Caenorhabditis elegans egg-laying behavior. Genetics. 2005 Mar;169(3):1425-36.

4 22. Wong DT. Duloxetine (LY 248686): an inhibitor of serotonin and noradrenaline

5 uptake and an antidepressant drug candidate. Expert opinion on investigational drugs.

$6 \quad 1998$ Oct; $7(10): 1691-9$.

723. Pandhare A, Pappu AS, Wilms H, Blanton MP, Jansen M. The antidepressant

8 bupropion is a negative allosteric modulator of serotonin type $3 \mathrm{~A}$ receptors.

9 Neuropharmacology. 2017 Feb;113(Pt A):89-99.

10 24. Januel D, Massot O, Poirier MF, Olie JP, Fillion G. Interaction of lithium with 5-

$11 \mathrm{HT}(1 \mathrm{~B})$ receptors in depressed unipolar patients treated with clomipramine and lithium

12 versus clomipramine and placebo: preliminary results. Psychiatry research. 2002 Aug

$13 \quad 30 ; 111(2-3): 117-24$.

14 25. Butterweck V, Nahrstedt A, Evans J, et al. In vitro receptor screening of pure

15 constituents of St. John's wort reveals novel interactions with a number of GPCRs.

16 Psychopharmacology. 2002 Jul;162(2):193-202.

17 26. Kang JH, Irwin DJ, Chen-Plotkin AS, et al. Association of cerebrospinal fluid

18 beta-amyloid 1-42, T-tau, P-tau181, and alpha-synuclein levels with clinical features of

19 drug-naive patients with early Parkinson disease. JAMA neurology. 2013

20 Oct;70(10):1277-87.

21 27. Defrancesco M, Marksteiner J, Kemmler G, Fleischhacker WW, Blasko I,

22 Deisenhammer EA. Severity of Depression Impacts Imminent Conversion from Mild 
1 Cognitive Impairment to Alzheimer's Disease. Journal of Alzheimer's disease : JAD.

$2 \quad 2017 ; 59(4): 1439-48$.

3 28. Nascimento KK, Silva KP, Malloy-Diniz LF, Butters MA, Diniz BS. Plasma and

4 cerebrospinal fluid amyloid-beta levels in late-life depression: A systematic review and

5 meta-analysis. Journal of psychiatric research. 2015 Oct;69:35-41.

6 29. Hoops S, Nazem S, Siderowf AD, et al. Validity of the MoCA and MMSE in the

7 detection of $\mathrm{MCl}$ and dementia in Parkinson disease. Neurology. $2009 \mathrm{Nov}$

$8 \quad 24 ; 73(21): 1738-45$.

9 30. The Parkinson Progression Marker Initiative (PPMI). Progress in neurobiology.

$102011 \mathrm{Dec} ; 95(4): 629-35$.

11 31. Pellecchia MT, Picillo M, Santangelo G, et al. Cognitive performances and DAT

12 imaging in early Parkinson's disease with mild cognitive impairment: a preliminary study.

13 Acta neurologica Scandinavica. 2015 May;131(5):275-81.

14 32. Marquie M, Locascio JJ, Rentz DM, et al. Striatal and extrastriatal dopamine

15 transporter levels relate to cognition in Lewy body diseases: an (11)C altropane positron

16 emission tomography study. Alzheimer's research \& therapy. 2014;6(5-8):52.

17 33. Schrag A, Siddiqui UF, Anastasiou Z, Weintraub D, Schott JM. Clinical variables

18 and biomarkers in prediction of cognitive impairment in patients with newly diagnosed

19 Parkinson's disease: a cohort study. The Lancet Neurology. 2017 Jan;16(1):66-75.

2034 Buddhala C, Loftin SK, Kuley BM, et al. Dopaminergic, serotonergic, and

21 noradrenergic deficits in Parkinson disease. Annals of clinical and translational

22 neurology. 2015 Oct;2(10):949-59. 
1 35. Ogawa T, Matson WR, Beal MF, et al. Kynurenine pathway abnormalities in

2 Parkinson's disease. Neurology. 1992 Sep;42(9):1702-6.

3 36. Politis $\mathrm{M}, \mathrm{Wu} \mathrm{K}$, Loane $\mathrm{C}$, et al. Staging of serotonergic dysfunction in

4 Parkinson's disease: an in vivo 11C-DASB PET study. Neurobiology of disease. 2010

5 Oct;40(1):216-21.

6 37. Kalaitzakis ME, Walls AJ, Pearce RK, Gentleman SM. Striatal Abeta peptide

7 deposition mirrors dementia and differentiates DLB and PDD from other parkinsonian

8 syndromes. Neurobiology of disease. 2011 Feb;41(2):377-84.

9 38. Shah N, Frey KA, Muller ML, et al. Striatal and Cortical beta-Amyloidopathy and

10 Cognition in Parkinson's Disease. Movement disorders : official journal of the Movement

11 Disorder Society. 2016 Jan;31(1):111-7.

12 39. Maloney JA, Bainbridge T, Gustafson A, et al. Molecular mechanisms of

13 Alzheimer disease protection by the A673T allele of amyloid precursor protein. The

14 Journal of biological chemistry. 2014 Nov 7;289(45):30990-1000.

15 40. Martiskainen H, Herukka SK, Stancakova A, et al. Decreased plasma beta-

16 amyloid in the Alzheimer's disease APP A673T variant carriers. Annals of neurology.

172017 Jul;82(1):128-32.

18 41. Fagan AM, Xiong C, Jasielec MS, et al. Longitudinal change in CSF biomarkers

19 in autosomal-dominant Alzheimer's disease. Science translational medicine. 2014 Mar

$20 \quad 5 ; 6(226): 226 r a 30$.

21 42. Bartels C, Wagner M, Wolfsgruber S, Ehrenreich H, Schneider A. Impact of SSRI

22 Therapy on Risk of Conversion From Mild Cognitive Impairment to Alzheimer's 
1 Dementia in Individuals With Previous Depression. The American journal of psychiatry.

22017 Nov 28:appiajp201717040404.

3 43. Kessing LV, Forman JL, Andersen PK. Do continued antidepressants protect

4 against dementia in patients with severe depressive disorder? International clinical

5 psychopharmacology. $2011 \mathrm{Nov;26(6):316-22.}$

6 44. Kessing LV, Sondergard L, Forman JL, Andersen PK. Antidepressants and

7 dementia. Journal of affective disorders. 2009 Sep;117(1-2):24-9.

8 45. Hajian-Tilaki K. Sample size estimation in epidemiologic studies. Caspian journal 9 of internal medicine. 2011 Fall;2(4):289-98.

10 46. Haasum Y, Fastbom J, Johnell K. Use of antidepressants in Parkinson's disease:

11 A Swedish register-based study of over 1.5 million older people. Parkinsonism \& related

12 disorders. 2016 Jun;27:85-8.

13 47. Menza M, Dobkin RD, Marin H, et al. A controlled trial of antidepressants in

14 patients with Parkinson disease and depression. Neurology. 2009 Mar 10;72(10):886-

1592.

16 48. Richard IH, McDermott MP, Kurlan R, et al. A randomized, double-blind, placebo-

17 controlled trial of antidepressants in Parkinson disease. Neurology. 2012 Apr

18 17;78(16):1229-36.

19 49. Dobkin RD, Menza M, Bienfait KL, et al. The impact of antidepressant treatment

20 on cognitive functioning in depressed patients with Parkinson's disease. The Journal of

21 neuropsychiatry and clinical neurosciences. 2010 Spring;22(2):188-95.

22 50. Moraros J, Nwankwo C, Patten SB, Mousseau DD. The association of

23 antidepressant drug usage with cognitive impairment or dementia, including Alzheimer 
Kotagal, et al. 27

1 disease: A systematic review and meta-analysis. Depression and anxiety. 2017

2 Mar;34(3):217-26.

3

4

5
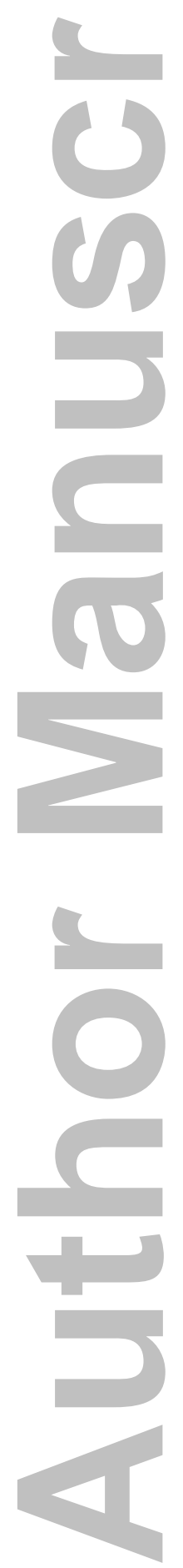

John Wiley \& Sons

This article is protected by copyright. All rights reserved. 
Table 1: Subjects Characteristics

\begin{tabular}{|c|c|c|c|}
\hline & $\begin{array}{l}\text { Study 1: PD PET } \\
\text { imaging cohort }\end{array}$ & $\begin{array}{l}\text { Study 2a: PPMI } \\
\text { Cross-sectional } \\
\text { Baseline cohort }\end{array}$ & $\begin{array}{l}\text { Study 2b: PPMI } \\
\text { Longitudinal cohort }\end{array}$ \\
\hline 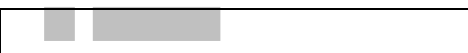 & \multicolumn{3}{|c|}{ Mean (SD) [min-max] or Count (\%) } \\
\hline $\mathrm{N}$ & 23 & 389 & 367 \\
\hline Baseline Age in years & $\begin{array}{c}66.2(6.7) \\
{[48-79]}\end{array}$ & $\begin{array}{c}61.8(9.6) \\
{[34-85]}\end{array}$ & $\begin{array}{c}61.7(9.7) \\
{[34-85]}\end{array}$ \\
\hline Male Sex & $17(74 \%)$ & $253(65 \%)$ & $238(65 \%)$ \\
\hline $\begin{array}{l}\text { Disease Duration in } \\
\text { years }\end{array}$ & $\begin{array}{c}4.9(4.1) \\
{[1-12]}\end{array}$ & $\begin{array}{c}1.9(2.0) \\
{[0-21]}\end{array}$ & $\begin{array}{c}1.9(2.0) \\
{[0-21]}\end{array}$ \\
\hline Hoehn and Yahr score & $\begin{array}{l}\text { HY1 }=6 \\
\text { HY2 }=15 \\
\text { HY3 }=2\end{array}$ & $\begin{array}{l}H Y 1=191 \\
H Y 2=198\end{array}$ & $\mathrm{HY} 1=180 \mathrm{HY} 2=187$ \\
\hline Years of education & $\begin{array}{c}16.9(3.1) \\
{[12-25]}\end{array}$ & $\begin{array}{c}15.6(3.0) \\
{[5-26]}\end{array}$ & $\begin{array}{c}15.5(2.9) \\
{[5-26]}\end{array}$ \\
\hline $\begin{array}{l}\text { Montreal Cognitive } \\
\text { Assessment (MoCA) } \\
\text { Score at Screening }\end{array}$ & $\begin{array}{c}25.6(2.4) \\
{[20-29]}\end{array}$ & $\begin{array}{c}27.2(2.3) \\
{[17-30]}\end{array}$ & $\begin{array}{l}27.2(2.1) \\
{[21-30]}\end{array}$ \\
\hline $\begin{array}{l}\text { Final MoCA Score at } \\
\text { the time of } \\
\text { event/censoring }\end{array}$ & NA & NA & $\begin{array}{c}26.4(3.3) \\
{[15-31]}\end{array}$ \\
\hline $\begin{array}{l}\text { Mean absolute decline } \\
\text { in MoCA score } \\
\text { between screening and } \\
\text { final score at the time } \\
\text { of event/censoring }\end{array}$ & NA & NA & $\begin{array}{l}0.8(3.0) \\
{[-6-+13]}\end{array}$ \\
\hline $\begin{array}{l}\text { Geriatric Depression } \\
\text { score at baseline }\end{array}$ & $\begin{array}{c}7.2(4.5)^{*} \\
{[1-15]}\end{array}$ & $\begin{array}{c}5.1(1.6) \\
{[0-10]}\end{array}$ & $\begin{array}{c}5.1(1.6) \\
{[0-10]}\end{array}$ \\
\hline $\begin{array}{l}\text { Cerebrospinal Fluid } A \beta- \\
42(\mathrm{pg} / \mathrm{ml}) \text { levels at } \\
\text { baseline }\end{array}$ & --- & $\begin{array}{l}371.5(101.5) \\
{[129.2-796.5]}\end{array}$ & $\begin{array}{l}373.2(102.2) \\
{[129.2-796.5]}\end{array}$ \\
\hline $\begin{array}{l}\text { Mean Cortical Amyloid } \\
\text { PiB PET Distribution } \\
\text { Volume Ratio }\end{array}$ & $\begin{array}{l}1.06(0.021) \\
{[1.04-1.11]}\end{array}$ & --- & --- \\
\hline
\end{tabular}

${ }^{*}$ This score represents the 30-item Geriatric Depression Scale score, whereas the PPMI cohorts used the 15-item Geriatric Depression Scale.

NA $=$ Not Applicable 
Table 2: Baseline PPMI cross-sectional multivariable linear regression analysis $(n=389)$

\begin{tabular}{|l|l|l|l|l|l|}
\hline \multicolumn{2}{|l|}{ Dependent Variable: Baseline CSF A $\beta-42$ (pg/ml); Overall Model F=2.35, p=0.0305 } \\
\hline Covariates & Beta & $\begin{array}{l}\text { Standard } \\
\text { Error }\end{array}$ & $\mathrm{t}$-score & $\mathrm{p}$-value & $\begin{array}{l}95 \% \\
\text { Confidence } \\
\text { Interval for Beta } \\
\text { values }\end{array}$ \\
\hline Age in years & -0.810 & 0.533 & -1.52 & 0.129 & $-1.859,0.238$ \\
\hline Male Sex & -28.971 & 11.002 & -2.63 & 0.009 & $-50.603,-7.338$ \\
\hline $\begin{array}{l}\text { Disease } \\
\text { duration in } \\
\text { years }\end{array}$ & 1.241 & 2.533 & 0.49 & 0.625 & $-3.740,6.221$ \\
\hline $\begin{array}{l}\text { Years of } \\
\text { Education }\end{array}$ & 0.067 & 1.718 & 0.04 & 0.969 & $-3.311,3.446$ \\
\hline $\begin{array}{l}\text { Geriatric } \\
\text { Depression } \\
\text { scale (GDS- } \\
\text { 15) score }\end{array}$ & -4.262 & 3.142 & -1.36 & 0.176 & $-10.440,1.915$ \\
\hline $\begin{array}{l}(+) \\
\text { Serotonin } \\
\text { medication } \\
\text { status for } \geq 6 \\
\text { months }\end{array}$ & -35.874 & 16.341 & -2.20 & 0.029 & $-68.004,-3.745$ \\
\hline
\end{tabular}


Table 3: Study $2 b$ Multivariable Proportional Hazard model of time to reach Montreal Cognitive Assessment Score of $\leq 20$.

\begin{tabular}{|l|l|l|l|l|l|}
\hline Overall Model Likelihood Ratio Chi square $=22.70, \mathrm{p}<0.0001,3$ & degrees of freedom \\
\hline Covariates & $\begin{array}{l}\text { Hazard } \\
\text { Ratio }\end{array}$ & $\begin{array}{l}\text { Standard } \\
\text { Error }\end{array}$ & Z-score & $p$-value & $\begin{array}{l}\text { 95\% Confidence } \\
\text { Interval for Hazard } \\
\text { Ratio }\end{array}$ \\
\hline $\begin{array}{l}\text { Mean bilateral } \\
\text { caudate DaT } \\
\text { SPECT binding } \\
\text { ratio at screening }\end{array}$ & 0.456 & 0.183 & -1.96 & 0.050 & $0.208,1.000$ \\
\hline $\begin{array}{l}\text { Serotoninergic } \\
\text { medication } \\
\text { status at } \\
\text { baseline }\end{array}$ & 0.223 & 0.165 & -2.03 & 0.043 & $0.052,0.952$ \\
\hline $\begin{array}{l}\text { Mean baseline } \\
\text { A } \beta-42(\mathrm{pg} / \mathrm{ml})\end{array}$ & 0.993 & 0.002 & -3.25 & 0.001 & $0.989,0.997$ \\
\hline
\end{tabular}




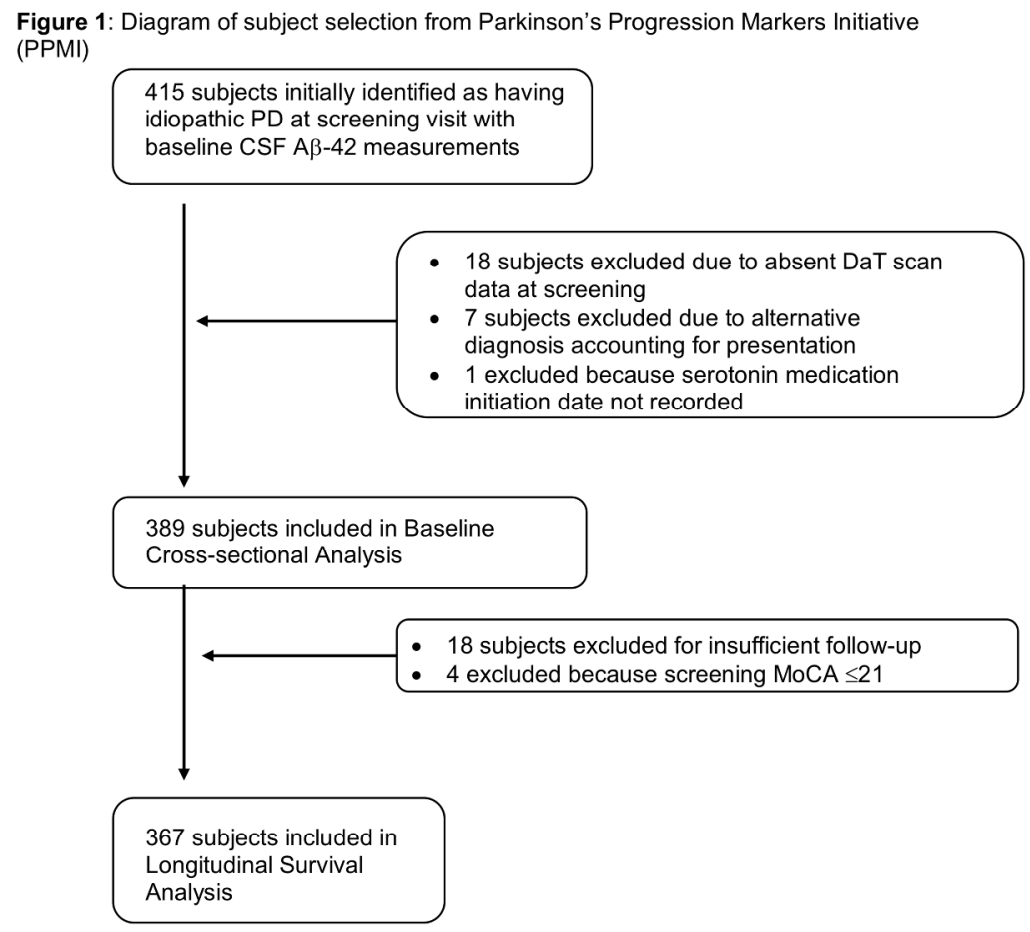

Figure 1: Diagram of subject selection from Parkinson's Progression Markers Initiative (PPMI)

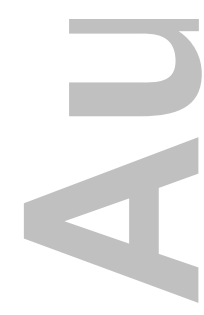

$215 \times 279 \mathrm{~mm}(300 \times 300 \mathrm{DPI})$ 


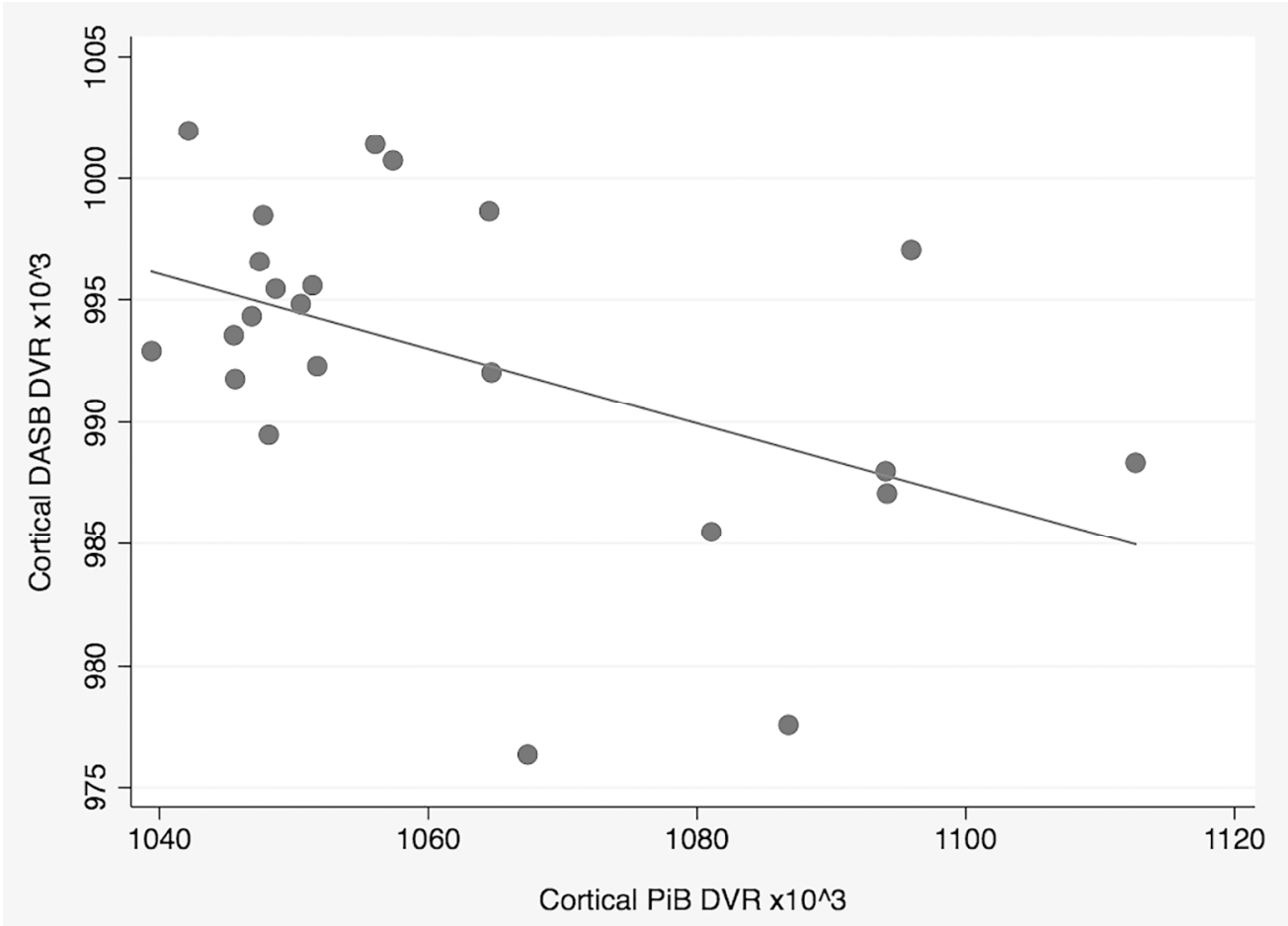

Figure 2: Cortical PiB (amyloid) vs DASB (serotonin) PET DVR $(n=23)$

$190 \times 138 \mathrm{~mm}(300 \times 300 \mathrm{DPI})$

John Wiley \& Sons

This article is protected by copyright. All rights reserved. 


\section{Supplementary Materials}

Supplementary Table 1: Exploratory Independent Cox-proportional hazard models testing bivariate associations with time to reach Montreal Cognitive Assessment score of $\leq 20$.

\begin{tabular}{|l|l|l|l|l|l|}
\hline $\begin{array}{l}\text { Independent } \\
\text { Variables each } \\
\text { tested in } \\
\text { separate models }\end{array}$ & $\begin{array}{l}\text { Hazard } \\
\text { Ratio }\end{array}$ & $\begin{array}{l}\text { Standard } \\
\text { Error }\end{array}$ & Z-score & $p$-value & $\begin{array}{l}95 \% \text { Confidence } \\
\text { Interval for Hazard } \\
\text { Ratio }\end{array}$ \\
\hline Age in years & 1.114 & 0.0273 & 4.41 & $<0.001$ & $1.062,1.169$ \\
\hline Male Sex & 2.316 & 1.144 & 1.70 & 0.089 & $0.880,6.096$ \\
\hline $\begin{array}{l}\text { Disease duration } \\
\text { in years }\end{array}$ & 1.015 & 0.095 & 0.16 & 0.873 & $0.845,1.220$ \\
\hline $\begin{array}{l}\text { Years of } \\
\text { Education }\end{array}$ & 0.996 & 0.0674 & -0.06 & 0.950 & $0.872,1.137$ \\
\hline $\begin{array}{l}\text { Baseline } \\
\text { Geriatric } \\
\text { Depression scale } \\
\text { (GDS-15) score }\end{array}$ & 0.990 & 0.116 & -0.09 & 0.930 & $0.786,1.246$ \\
\hline $\begin{array}{l}(+) \text { Serotonin } \\
\text { medication at } \\
\text { baseline }\end{array}$ & 0.329 & 0.241 & -1.51 & 0.130 & $0.078,1.386$ \\
\hline $\begin{array}{l}\text { Mean bilateral } \\
\text { caudate DaT } \\
\text { SPECT binding } \\
\text { ratio at screening }\end{array}$ & 0.415 & 0.157 & -2.32 & 0.020 & $0.197,0.871$ \\
\hline $\begin{array}{l}\text { Mean baseline } \\
\text { A } \beta-42 \text { (pg/ml) }\end{array}$ & 0.992 & 0.002 & -3.60 & $<0.001$ & $0.988,0.996$ \\
\hline
\end{tabular}


Table 1: Subjects Characteristics

\begin{tabular}{|c|c|c|c|}
\hline & $\begin{array}{l}\text { Study 1: PD PET } \\
\text { imaging cohort }\end{array}$ & \begin{tabular}{|l|} 
Study 2a: PPMI \\
Cross-sectional \\
Baseline cohort
\end{tabular} & $\begin{array}{l}\text { Study 2b: PPMI } \\
\text { Longitudinal cohort }\end{array}$ \\
\hline TI & \multicolumn{3}{|c|}{ Mean (SD) [min-max] or Count (\%) } \\
\hline $\mathrm{N}$ & 23 & 389 & 367 \\
\hline Baseline Age in years & $\begin{array}{c}66.2(6.7) \\
{[48-79]} \\
\end{array}$ & $\begin{array}{c}61.8(9.6) \\
{[34-85]}\end{array}$ & $\begin{array}{c}61.7(9.7) \\
{[34-85]} \\
\end{array}$ \\
\hline Male Sex & $17(74 \%)$ & $253(65 \%)$ & $238(65 \%)$ \\
\hline $\begin{array}{l}\text { Disease Duration in } \\
\text { years }\end{array}$ & $\begin{array}{c}4.9(4.1) \\
{[1-12]}\end{array}$ & $\begin{array}{c}1.9(2.0) \\
{[0-21]}\end{array}$ & $\begin{array}{c}1.9(2.0) \\
{[0-21]}\end{array}$ \\
\hline Hoehn and Yahr score & $\begin{array}{l}\text { HY1 }=6 \\
\text { HY2 }=15 \\
\text { HY3 }=2\end{array}$ & $\begin{array}{l}\mathrm{HY} 1=191 \\
\mathrm{HY} 2=198\end{array}$ & $\mathrm{HY} 1=180 \mathrm{HY} 2=187$ \\
\hline Years of education & $\begin{array}{c}16.9(3.1) \\
{[12-25]}\end{array}$ & $\begin{array}{c}15.6(3.0) \\
{[5-26]}\end{array}$ & $\begin{array}{c}15.5(2.9) \\
{[5-26]}\end{array}$ \\
\hline $\begin{array}{l}\text { Montreal Cognitive } \\
\text { Assessment (MoCA) } \\
\text { Score at Screening }\end{array}$ & $\begin{array}{c}25.6(2.4) \\
{[20-29]}\end{array}$ & $\begin{array}{c}27.2(2.3) \\
{[17-30]}\end{array}$ & $\begin{array}{c}27.2(2.1) \\
{[21-30]}\end{array}$ \\
\hline $\begin{array}{l}\text { Final MoCA Score at } \\
\text { the time of } \\
\text { event/censoring }\end{array}$ & NA & NA & $\begin{array}{c}26.4(3.3) \\
{[15-31]}\end{array}$ \\
\hline $\begin{array}{l}\text { Mean absolute decline } \\
\text { in MoCA score } \\
\text { between screening and } \\
\text { final score at the time } \\
\text { of event/censoring }\end{array}$ & NA & NA & $\begin{array}{l}0.8(3.0) \\
{[-6-+13]}\end{array}$ \\
\hline $\begin{array}{l}\text { Geriatric Depression } \\
\text { score at baseline }\end{array}$ & $\begin{array}{c}7.2(4.5)^{\star} \\
{[1-15]}\end{array}$ & $\begin{array}{c}5.1(1.6) \\
{[0-10]}\end{array}$ & $\begin{array}{c}5.1(1.6) \\
{[0-10]}\end{array}$ \\
\hline $\begin{array}{l}\text { Cerebrospinal Fluid } A \beta- \\
42(\mathrm{pg} / \mathrm{ml}) \text { levels at } \\
\text { baseline }\end{array}$ & --- & $\begin{array}{l}371.5(101.5) \\
{[129.2-796.5]}\end{array}$ & $\begin{array}{l}373.2(102.2) \\
{[129.2-796.5]}\end{array}$ \\
\hline $\begin{array}{l}\text { Mean Cortical Amyloid } \\
\text { PiB PET Distribution } \\
\text { Volume Ratio }\end{array}$ & $\begin{array}{l}1.06(0.021) \\
{[1.04-1.11]}\end{array}$ & --- & --- \\
\hline
\end{tabular}

${ }^{*}$ This score represents the 30-item Geriatric Depression Scale score, whereas the PPMI cohorts used the 15-item Geriatric Depression Scale.

NA $=$ Not Applicable 
Table 2: Baseline PPMI cross-sectional multivariable linear regression analysis $(n=389)$

\begin{tabular}{|l|l|l|l|l|l|}
\hline \multicolumn{2}{|l|}{ Dependent Variable: Baseline CSF A $\beta-42$ (pg/ml); Overall Model F=2.35, p=0.0305 } \\
\hline Covariates & Beta & $\begin{array}{l}\text { Standard } \\
\text { Error }\end{array}$ & $\mathrm{t}$-score & $\mathrm{p}$-value & $\begin{array}{l}95 \% \\
\text { Confidence } \\
\text { Interval for Beta } \\
\text { values }\end{array}$ \\
\hline Age in years & -0.810 & 0.533 & -1.52 & 0.129 & $-1.859,0.238$ \\
\hline Male Sex & -28.971 & 11.002 & -2.63 & 0.009 & $-50.603,-7.338$ \\
\hline $\begin{array}{l}\text { Disease } \\
\text { duration in } \\
\text { years }\end{array}$ & 1.241 & 2.533 & 0.49 & 0.625 & $-3.740,6.221$ \\
\hline $\begin{array}{l}\text { Years of } \\
\text { Education }\end{array}$ & 0.067 & 1.718 & 0.04 & 0.969 & $-3.311,3.446$ \\
\hline $\begin{array}{l}\text { Geriatric } \\
\text { Depression } \\
\text { scale (GDS- } \\
\text { 15) score }\end{array}$ & -4.262 & 3.142 & -1.36 & 0.176 & $-10.440,1.915$ \\
\hline $\begin{array}{l}(+) \\
\text { Serotonin } \\
\text { medication } \\
\text { status for } \geq 6 \\
\text { months }\end{array}$ & -35.874 & 16.341 & -2.20 & 0.029 & $-68.004,-3.745$ \\
\hline
\end{tabular}


Table 3: Study $2 b$ Multivariable Proportional Hazard model of time to reach Montreal Cognitive Assessment Score of $\leq 20$.

\begin{tabular}{|l|l|l|l|l|l|}
\hline Overall Model Likelihood Ratio Chi square $=22.70, \mathrm{p}<0.0001,3$ degrees of freedom \\
\hline Covariates & $\begin{array}{l}\text { Hazard } \\
\text { Ratio }\end{array}$ & $\begin{array}{l}\text { Standard } \\
\text { Error }\end{array}$ & Z-score & $p$-value & $\begin{array}{l}\text { 95\% Confidence } \\
\text { Interval for Hazard } \\
\text { Ratio }\end{array}$ \\
\hline $\begin{array}{l}\text { Mean bilateral } \\
\text { caudate DaT } \\
\text { SPECT binding } \\
\text { ratio at screening }\end{array}$ & 0.456 & 0.183 & -1.96 & 0.050 & $0.208,1.000$ \\
\hline $\begin{array}{l}\text { Serotoninergic } \\
\text { medication } \\
\text { status at } \\
\text { baseline }\end{array}$ & 0.223 & 0.165 & -2.03 & 0.043 & $0.052,0.952$ \\
\hline $\begin{array}{l}\text { Mean baseline } \\
\text { A } \beta-42(\mathrm{pg} / \mathrm{ml})\end{array}$ & 0.993 & 0.002 & -3.25 & 0.001 & $0.989,0.997$ \\
\hline
\end{tabular}

